\title{
Screening of cassava effluent- a proposed weed biocontrol agent for its effect on soil nutrients and microbial population
}

\author{
Olatunde Philip Ayodele* and Segun Oluwatomiwa Oladele \\ Department of Agronomy, Adekunle Ajasin University Akungba-Akoko, Ondo State, Nigeria \\ [Received: September 09, 2019 Accepted: December 23, 2019 Published Online: January 22, 2020]
}

\begin{abstract}
Weed management in crop production has the objective of reducing plant nutrient competition with minimal effect on soil microbial load. Hence, it is important to investigate the effect of botanicals used for weed management in this regard. The effect of cassava effluent (CE) concentrations of 60, 120, 180 and 240 $\mu \mathrm{g} \mathrm{CN} / \mathrm{kg}$ (CN is a universal chemical symbol for cyanide) soil that were applied one, two, three and four times, was evaluated on soil nutrients and microbial load in a $4 \times 4$ factorial arrangement. Control treatment (without CE) was incorporated into the experiment in an incomplete factorial design. This was laid out in completely randomized design in the screen-house. Results showed that CE concentration and frequency of application altered the $\mathrm{C}, \mathrm{Ca}, \mathrm{Mg}, \mathrm{Na}, \mathrm{K}, \mathrm{Cu}, \mathrm{Fe}, \mathrm{Mn}$ and $\mathrm{Zn}$ contents of the soil. CE concentration and frequency of application had significant interaction $(p<0.05)$ on all the plant nutrients analysed. $C E$ concentration of 60 and $120 \mu \mathrm{g} \mathrm{CN/kg}$ soil applied one to four times had available P concentrations lesser than the control treatment. Contrarily, P increased by $45 \%$ when CE of $240 \mu \mathrm{g} C N / \mathrm{kg}$ soil was applied three times. Significant $(p<0.05)$ interaction between $C E$ concentration and application frequency markedly decreased culturable bacterial population, while fungal population was increased by some interactions. The study concluded that application of CE for weed control has moderating effect on soil nutrients and microbial load. Hence, its adoption for weed control requires the understanding of its influence on chemical and biological properties of soil.
\end{abstract}

Keywords: Cassava effluent, soil nutrient, microbial load, weed control

\section{Introduction}

Screening of plant extracts as biocontrol agents for weed management goes beyond evaluation of herbistatic and herbicidal efficacies. It is important to investigate the effect of biocontrol agents on factors that affect crop growth as well. Weed management in crop production has the objective of reducing competition for soil nutrients and other limited growth factors. Previous studies showed that attenuating the negative effect of weeds improves crop yield (Aladesanwa and Ayodele, 2011; Akadiri et al., 2017). However, it is important to ensure that the weed management strategy employed does not promote competition by adversely affecting soil nutrients and its biological component. The beneficial roles of soil microorganisms in nutrient cycling (Kumar et al., 2015), solubilisation and absorption of plant nutrients (Kumar et al., 2017) justify that weed management practices should not distress the soil microbial population.

The use of synthetic herbicides for weed control has generated concerns; as they negatively impact the soil environment (Romano-Armada et al., 2017). The associated hazards of herbicide application such as soil nutrient uptake interception (McLay and Robson, 1992), reduced activities of beneficial soil organisms (GauppBerghausen et al., 2015) and contamination of freshwater (Masiol et al., 2018) have justified the quest for other effective weed management practices that are environment friendly.

Recently, attention is being given to the use of plants or plant products as alternative to synthetic herbicides for weed control (Arif et al., 2015). The use of botanicals for weed control could be by direct application of allelopathic extracts or cultural means such as planting of allelopathic plant, intercropping with allelopathic plant, mulching and the use of cover crops (Bajwa et al., 2015; Jabran et al., 2015). In Central Tongu District of Ghana, the use of cassava effluent (CE) for weed control has been reported (Adabie, 2015). Also, studies conducted in Nigeria suggested that CE could be used for weed control based on its phytotoxicity (Nwakaudu et al., 2012; Fayinminnu et al., 2013; Eze and Onyilide, 2015).

\footnotetext{
*Email: olatunde.ayodele@aaua.edu.ng
} 
The phytotoxic nature of $\mathrm{CE}$ has been linked to the presence of cyanide $(\mathrm{CN})$ that inhibits major plant processes such as respiration, $\mathrm{CO}_{2}$ and nitrate assimilation, and photosynthetic electron transfer (Kremer and Souissi, 2001). However, cyanide concentration in cassava varies with respect to variety, age of cassava, and agro-ecological conditions of the area where it is cultivated (Agiriga and Iwe, 2016). Hence, it is important to evaluate CE for weed control in relation to $\mathrm{CN}$ applied through it, as against the quantity of CE applied.

Plant extracts end up in the soil when applied directly by chemigation or indirectly by foliar application. Thus, this study aimed at investigating the effect of CE concentration and frequency of application on soil nutrients and microorganisms.

\section{Materials and Methods}

\section{Experimental site}

The experiment was conducted in the screen-house of the Institute of Agricultural Research and Training, Ibadan $\left(7^{\circ} 31^{\prime} \mathrm{N} 3^{\circ} 45^{\prime} \mathrm{E}\right)$, located in the forest-savanna transition agro-ecological zone of Nigeria. The temperature and the relative humidity in the screen-house fluctuated between $24-33^{\circ} \mathrm{C}$ and $52-79 \%$, respectively, during the experiment.

\section{Materials}

Fresh CE was obtained from the Cassava Processing Section of International Institute of Tropical Agriculture (IITA) Ibadan. The CE was extracted from cassava tubers that were processed within a day. The extraction involved peeling, grinding and pressing of the cassava tuber. The CE was collected on the day of processing and application; hence, it was not stored. The physicochemical properties of the $\mathrm{CE}$ were determined and are presented in Table 1.

The nitrogen $(\mathrm{N})$ content of the $\mathrm{CE}$ was determined using modified micro-kjeldahl digestion method (Nelson and Sommers, 1973). The phosphorus (P) was analysed using a $\mathrm{H}_{2} \mathrm{SO}_{4}-\mathrm{HNO}_{3}$ acid digestion procedure and the digest was analysed for ortho $\mathrm{P}$ using a colorimetric assay (Murphy and Riley, 1962). Potassium (K) and sodium (Na) of the effluent were determined by flame photometry (Black, 1965). The calcium (Ca), magnesium (Mg), iron $(\mathrm{Fe})$, copper $(\mathrm{Cu})$, and zinc $(\mathrm{Zn})$ concentrations were analysed using Agilent Atomic Absorption Spectrometer model 280Z AA. The total suspended solids (TSS) and the total dissolved solids (TDS) were measured by the method 2540B of the American Public Health Association (APHA, 1995) and the $\mathrm{pH}$ was determined with Hanna $\mathrm{pH} 211$ instrument.
The CE was analysed for $\mathrm{CN}$ using Ninhydrin-based spectrophotometric method (Surleva et al., 2013). Hence, the equivalent amount of $\mathrm{CE}$ with the desired $\mathrm{CN}$ concentration required as experimental treatment was determined. Different volumes of CE with corresponding $\mathrm{CN}$ concentrations needed as experimental treatment were diluted with water and made up to same volume to facilitate equal spread when applied to the soil. This standardization was repeated weekly; at each time of $\mathrm{CE}$ application, maintaining same concentration levels.

Topsoil was collected from arable crop farmland within the premises of the Institute of Agricultural Research and Training, Ibadan where agro chemicals were not applied for the past five years. The soil collected is clay loam containing $378 \mathrm{~g} \mathrm{~kg}^{-1}$ sand, $239 \mathrm{~g} \mathrm{~kg}^{-1}$ silt and $383 \mathrm{~g} \mathrm{~kg}^{-1}$ clay. This was air dried, sieved and homogenized.

\section{Experimental treatments and design}

The experimental treatments were four levels of $\mathrm{CE}$ concentration $(60,120,180$, and $240 \mu \mathrm{g} \mathrm{CN} / \mathrm{kg}$ soil) in factorial combination with four levels of application frequency (one, two, three and four times). Control treatment where CE was not applied was also included. These were laid out in three replications in completely randomized design.

\section{Application of CE to potted soil}

The pot used for this experiment is 16.5 and $13.5 \mathrm{~cm}$ in length and breadth, respectively. Sixty pots were filled with the prepared soil at $5 \mathrm{~kg}$ per pot and these were arranged in the screen-house. The potted soil was watered every other day for five weeks to facilitate natural weed emergence and growth. Cassava effluent was not applied to twelve pots throughout the experiment. From the sixth week, standardized CE concentrations were applied to the soil in the remaining pots by drenching. Application of the same standardized CE concentration that was initially applied to the potted soil at the sixth week was repeated weekly till the ninth week. However, the application ceased at sixth, seventh, eighth and ninth week in some pots to achieve frequency of application of the standardized $\mathrm{CE}$ concentrations that is one to four times.

\section{Data collection}

\section{Soil chemical properties}

Soil sample was taken from each pot for chemical analysis immediately after the weed sampling at the end of the twelfth week into the experiment. Soil $\mathrm{pH}$ was determined at a soil to water ratio of 1: 2 (IITA, 1979). Soil organic carbon (SOC) was determined by the method of 
Table 1: Physicochemical analysis of cassava effluent

\begin{tabular}{|c|c|c|c|c|c|c|c|c|c|c|c|c|}
\hline N (\%) & \multicolumn{2}{|l|}{$P(\%)$} & \multicolumn{2}{|c|}{ K (\%) } & \multicolumn{2}{|l|}{$\mathrm{Ca}(\%)$} & \multicolumn{2}{|c|}{$\operatorname{Mg}(\%)$} & \multicolumn{2}{|c|}{$\mathrm{Na}\left(\mathrm{mg} \mathrm{L}^{-1}\right)$} & \multicolumn{2}{|c|}{$\operatorname{Mn}\left(\mathrm{mg} \mathrm{L}^{-1}\right)$} \\
\hline 0.05 & 0.02 & & 0.44 & & 0.06 & & 0.03 & & 20.79 & & 1.83 & \\
\hline $\mathrm{Fe}\left(\mathrm{mg} \mathrm{L}^{-1}\right)$ & $\mathrm{Cu}(\mathrm{m}$ & $\left.L^{-1}\right)$ & $\mathrm{Zn}(\mathrm{n}$ & $\left.L^{-1}\right)$ & $\mathrm{CN}(\mathrm{m}$ & $\left.L^{-1}\right)$ & pH & & TSS (mg & $\left.\mathrm{L}^{-1}\right)$ & TDS ( & $\left.\mathrm{g} \mathrm{L}^{-1}\right)$ \\
\hline 11.90 & 1.33 & & 2.32 & & 12.70 & & 3.90 & & 1.53 & & 6300 & \\
\hline $\begin{array}{c}\mathbf{C E} \\
(\mu \mathrm{g} \mathrm{CN} / \mathrm{kg})\end{array}$ & $\begin{array}{l}\text { SOC } \\
\text { g/kg }\end{array}$ & $\begin{array}{l}\text { T.N } \\
\text { g/kg }\end{array}$ & $\begin{array}{l}\mathrm{P} \\
\mathrm{mg} / \mathrm{kg}\end{array}$ & $\begin{array}{l}\mathrm{K} \\
\mathrm{cmol} / \mathrm{kg}\end{array}$ & $\begin{array}{l}\mathrm{Ca} \\
\mathrm{cmol} / \mathrm{kg}\end{array}$ & $\begin{array}{l}\mathrm{Mg} \\
\mathrm{cmol} / \mathrm{kg}\end{array}$ & $\begin{array}{l}\mathrm{Na} \\
\mathrm{cmol} / \mathrm{kg}\end{array}$ & $\begin{array}{l}\mathrm{Mn} \\
\mathrm{mg} / \mathrm{kg}\end{array}$ & $\begin{array}{l}\mathrm{Cu} \\
\mathrm{mg} / \mathrm{kg}\end{array}$ & $\begin{array}{l}\mathrm{Fe} \\
\mathrm{mg} / \mathrm{kg}\end{array}$ & $\begin{array}{l}\mathrm{Zn} \\
\mathrm{mg} / \mathrm{kg}\end{array}$ & $\begin{array}{l}\mathrm{pH} \\
\left(\mathrm{H}_{2} \mathrm{O}\right)\end{array}$ \\
\hline 60 & $16.9 \mathrm{a}$ & 1.5 & $7.68 \mathrm{e}$ & $0.89 \mathrm{~d}$ & $1.89 \mathrm{~b}$ & $2.34 \mathrm{~b}$ & $1.82 \mathrm{c}$ & $13.94 \mathrm{~d}$ & $2.48 \mathrm{c}$ & $205.92 \mathrm{c}$ & $0.89 b c$ & $6.98 \mathrm{~b}$ \\
\hline 120 & $15.6 \mathrm{~b}$ & 1.4 & $10.14 d$ & $1.29 \mathrm{c}$ & $2.00 \mathrm{a}$ & $2.60 \mathrm{a}$ & $1.92 \mathrm{bc}$ & $14.79 \mathrm{c}$ & $2.86 \mathrm{~b}$ & $234.67 \mathrm{~b}$ & $1.00 \mathrm{a}$ & 7.11ab \\
\hline 180 & 16.1ab & 1.2 & $11.76 \mathrm{~b}$ & $1.39 b$ & $1.64 \mathrm{~d}$ & $2.28 b$ & $1.97 \mathrm{~b}$ & $14.97 \mathrm{~b}$ & $2.73 b c$ & $232.16 \mathrm{~b}$ & $0.99 \mathrm{a}$ & 7.15ab \\
\hline 240 & $14.5 \mathrm{c}$ & 1.3 & $14.49 \mathrm{a}$ & $1.84 \mathrm{a}$ & $1.61 \mathrm{e}$ & $2.32 b$ & $2.14 a$ & $18.94 \mathrm{a}$ & $3.30 \mathrm{a}$ & 291.16a & $0.91 \mathrm{~b}$ & $7.29 \mathrm{a}$ \\
\hline Control & $16.2 \mathrm{ab}$ & 1.2 & $11.33 \mathrm{c}$ & $0.74 \mathrm{e}$ & $1.70 \mathrm{c}$ & $2.33 b$ & $1.50 \mathrm{~d}$ & $7.95 \mathrm{e}$ & $1.97 \mathrm{~d}$ & $120.67 \mathrm{~d}$ & $0.81 \mathrm{c}$ & $6.75 \mathrm{c}$ \\
\hline
\end{tabular}

Means in a column followed by the same letter are not significantly different according to DMRT $(\mathrm{p}=0.05)$.

Walkley and Black (1934). Micro-kjeldahl digestion method was used to determine the total nitrogen (Kjeldahl, 1983). Available phosphorus (P) was determined by Bray and Kurtz (1945) No.1 method. Exchangeable bases were extracted with neutral ammonium acetate $\left(1 \mathrm{M} \mathrm{NH}_{4} \mathrm{OAc}, \mathrm{pH}\right.$ 7.0). Potassium $(\mathrm{K})$ and sodium $(\mathrm{Na})$ in the extract were determined by flame photometry (Black, 1965). Versenate EDTA titration method was used to determine calcium $(\mathrm{Ca})$ and magnesium (Mg) (Jackson, 1962). Trace elements in the soils ( $\mathrm{Fe}, \mathrm{Mn}, \mathrm{Cu}$, and $\mathrm{Zn}$ ) were extracted by digesting the samples with mixture of concentrated nitric acid $\left(\mathrm{HNO}_{3}\right)$ and hydrogen chloride (HCI) and determined by Atomic Absorption Spectrophotometry (AAS) method (Soylak et al., 2003).

\section{Soil microbial data}

Part of the soil sample taken from each pot at the twelfth week was used for microbial enumeration. Nutrient agar (NA) was used for the enumeration of total heterotrophic bacteria by the pour plate method. Incubation was done at $30^{\circ} \mathrm{C}$ for $24-48 \mathrm{~h}$. Isolates from this were characterized based on cultural characteristics, staining reactions and biochemical reactions and identification was done with reference to Bergey's manual of systemic bacteriology. Potato dextrose agar (PDA) was used for enumeration of fungi. Inoculation was done and placed at $25^{\circ} \mathrm{C}$ for $48 \mathrm{~h}$. The fungal isolates were characterized as described by Barnett and Hunter (1972).

\section{Data analysis}

Data were subjected to analysis of variance. Treatment means were separated by using DMRT at $p<0.05$. These were performed using IBM SPSS Statistics 23 software (George and Mallery, 2016).

\section{Results}

\section{Effect of CE concentration on soil mineral elements}

The $\mathrm{CE}$ concentration applied to the soil had significant effect on soil C, Mg, Na, K, P, Mn, Cu, Fe and Zn (Table 2). In contrast, $\mathrm{CE}$ concentration did not significantly influence the total soil N. Cassava effluent concentration did not significantly increase soil organic carbon (SOC) rather CE of $240 \mu \mathrm{g} \mathrm{CN} / \mathrm{kg}$ soil resulted in significantly reduced SOC of $10 \%$ compared to the control treatment. Potted soil treated with $60 \mu \mathrm{g} \mathrm{CN} / \mathrm{kg}$ soil had the highest SOC while those treated with $240 \mu \mathrm{g} \mathrm{CN} / \mathrm{kg}$ soil had the least.

Potted soil treated with $\mathrm{CE}$ of 60 and $120 \mu \mathrm{g} \mathrm{CN} / \mathrm{kg}$ soil had $\mathrm{Ca}$ concentrations that were significantly higher $(p<0.05)$ than the control treatment by $11 \%$ and $18 \%$, respectively, while those of 180 and $240 \mu \mathrm{g} \mathrm{CN} / \mathrm{kg}$ soil were significantly lesser by $4 \%$ and $5 \%$, respectively. Cassava effluent concentration of $120 \mu \mathrm{g} \mathrm{CN} / \mathrm{kg}$ soil resulted in the highest concentration of soil $\mathrm{Mg}$. It had $\mathrm{Mg}$ concentration that was $12 \%$ more than the control treatment and that was significantly higher $(\mathrm{p}<0.05)$ than all other treatments.

The concentrations of soil $\mathrm{Na}, \mathrm{K}$ and $\mathrm{Mn}$ increased significantly $(p<0.05)$ with increasing concentration of CE. Hence, soil treated with $240 \mu \mathrm{g} \mathrm{CN} / \mathrm{kg}$ soil had the highest concentration of these mineral elements. The treatment resulted in soil $\mathrm{Na}, \mathrm{K}$ and $\mathrm{Mn}$ that were $42 \%$, $135 \%$ and $138 \%$ higher than the control treatment, respectively. Similarly, $240 \mu \mathrm{g} \mathrm{CN} / \mathrm{kg}$ soil had the highest concentration of $\mathrm{P}$ with $28 \%$ increase over the control treatment while $60 \mu \mathrm{g} \mathrm{CN} / \mathrm{kg}$ soil had the least with $32 \%$ decrease. These treatments were significantly different $(p<0.05)$ from the control treatment. 
Concentrations of $\mathrm{Cu}$ and $\mathrm{Fe}$ increased significantly $(p<0.05)$ in soil treated with CE of $60,120,180$ or 240 $\mu \mathrm{g} \mathrm{CN} / \mathrm{kg}$ compared to the control treatment. Soil treated with $240 \mu \mathrm{g} \mathrm{CN} / \mathrm{kg}$ soil had the highest concentration of these mineral elements. The $\mathrm{Cu}$ and $\mathrm{Fe}$ concentrations in this treatment increased by $23 \%$ and $141 \%$, respectively, over the control treatment. Cassava effluent concentration did not significantly reduce soil $\mathrm{Zn}$ compared to the control treatment rather potted soil treated with 120,180 or $240 \mu \mathrm{g} \mathrm{CN} / \mathrm{kg}$ soil had significantly increased $\mathrm{Zn}$ by $12-23 \%$.

Potted soil treated with CE concentrations of 60,120 , 180 or $240 \mu \mathrm{g} \mathrm{CN} / \mathrm{kg}$ soil had significantly increased soil $\mathrm{pH}$ compared to the control treatment. The soil $\mathrm{pH}$ increased by $0.23-8 \%$ with increasing $\mathrm{CE}$ concentration.

\section{Effect of frequency of CE application on soil mineral elements}

Frequency of $\mathrm{CE}$ application had significant effect on all $(\mathrm{C}, \mathrm{N}, \mathrm{Ca}, \mathrm{Mg}, \mathrm{Na}, \mathrm{K}, \mathrm{Cu}, \mathrm{Fe}, \mathrm{Mn}$ and $\mathrm{Zn}$ ) the mineral elements analysed (Table 3 ). There seemed to be no clear trend of SOC response to the frequency of CE application. However, four applications of CE significantly increased SOC by $8 \%$ while two applications of CE reduced SOC by $9 \%$ compared to the control treatment. Similarly, four applications of CE resulted in soil $\mathrm{N}$ that was significantly higher than those that had lesser frequency of $\mathrm{CE}$ application and the control treatment. It had soil $\mathrm{N}$ that was $33 \%$ more than the control treatment. Frequency of CE application lesser than four resulted in soil $\mathrm{N}$ that was comparable to the control treatment.

Table 3: Effect of frequency of CE application on soil mineral elements

\begin{tabular}{|c|c|c|c|c|c|c|c|c|c|c|c|c|}
\hline Frequency & $\begin{array}{l}\text { SOC } \\
\mathrm{g} / \mathrm{kg}\end{array}$ & $\begin{array}{l}\text { T.N } \\
\text { g/kg }\end{array}$ & $\begin{array}{l}\mathrm{P} \\
\mathrm{mg} / \mathrm{kg}\end{array}$ & $\begin{array}{l}\mathrm{K} \\
\mathrm{cmol} / \mathrm{kg}\end{array}$ & $\begin{array}{l}\mathrm{Ca} \\
\mathrm{cmol} / \mathrm{kg}\end{array}$ & $\begin{array}{l}\mathrm{Mg} \\
\mathrm{cmol} / \mathrm{kg}\end{array}$ & $\begin{array}{l}\mathrm{Na} \\
\mathrm{cmol} / \mathrm{kg}\end{array}$ & $\begin{array}{l}\mathrm{Mn} \\
\mathrm{mg} / \mathrm{kg}\end{array}$ & $\begin{array}{l}\mathrm{Cu} \\
\mathrm{mg} / \mathrm{kg}\end{array}$ & $\begin{array}{l}\mathrm{Fe} \\
\mathrm{mg} / \mathrm{kg}\end{array}$ & $\begin{array}{l}\mathrm{Zn} \\
\mathrm{mg} / \mathrm{kg}\end{array}$ & $\begin{array}{l}\mathrm{pH} \\
\left(\mathrm{H}_{2} \mathrm{O}\right)\end{array}$ \\
\hline 1 & $15.0 \mathrm{c}$ & $1.3 b$ & $11.18 b$ & $1.17 \mathrm{c}$ & $1.74 \mathrm{c}$ & $2.48 \mathrm{a}$ & $1.71 \mathrm{c}$ & $13.70 \mathrm{~d}$ & $2.43 \mathrm{c}$ & $221.75 \mathrm{~d}$ & $0.67 \mathrm{c}$ & $7.14 \mathrm{ab}$ \\
\hline 2 & $14.8 \mathrm{c}$ & $1.3 b$ & $10.77 \mathrm{c}$ & $1.35 \mathrm{~b}$ & $1.82 b$ & $2.49 \mathrm{a}$ & $1.95 \mathrm{~b}$ & $14.55 \mathrm{c}$ & $2.98 b$ & $233.08 \mathrm{c}$ & $1.07 \mathrm{a}$ & $7.28 \mathrm{a}$ \\
\hline 3 & $15.8 b c$ & $1.2 b$ & $11.29 \mathrm{a}$ & $1.37 \mathrm{~b}$ & $1.59 \mathrm{e}$ & $2.34 \mathrm{~b}$ & $2.11 \mathrm{a}$ & $15.07 \mathrm{~b}$ & $2.48 \mathrm{c}$ & $243.75 b$ & $1.03 \mathrm{a}$ & 7.11ab \\
\hline 4 & $17.5 \mathrm{a}$ & $1.6 \mathrm{a}$ & $10.84 \mathrm{c}$ & $1.53 \mathrm{a}$ & $1.99 \mathrm{a}$ & $2.24 \mathrm{c}$ & $2.08 \mathrm{a}$ & $19.33 \mathrm{a}$ & $3.48 \mathrm{a}$ & $265.33 \mathrm{a}$ & $1.04 \mathrm{a}$ & $7.00 \mathrm{~b}$ \\
\hline Control & $16.2 \mathrm{~b}$ & $1.2 \mathrm{~b}$ & $11.33 \mathrm{a}$ & $0.74 \mathrm{~d}$ & $1.70 \mathrm{~d}$ & $2.33 b$ & $1.50 \mathrm{~d}$ & $7.95 \mathrm{e}$ & $1.97 \mathrm{~d}$ & $120.67 \mathrm{e}$ & $0.82 \mathrm{~b}$ & $6.75 \mathrm{c}$ \\
\hline
\end{tabular}

Means in a column followed by the same letter are not significantly different according to DMRT ( $p=0.05)$

Table 4: Interaction effect between $\mathrm{CE}$ concentration and frequency of application on soil mineral elements

\begin{tabular}{|c|c|c|c|c|c|c|c|c|c|c|c|c|c|}
\hline $\begin{array}{c}\mathbf{C E} \\
(\mu \mathrm{g} \mathrm{CN} / \mathrm{kg}) \\
\end{array}$ & Freq & $\begin{array}{l}\text { SOC } \\
\mathrm{g} / \mathrm{kg}\end{array}$ & $\begin{array}{l}\text { T.N } \\
\mathrm{g} / \mathrm{kg}\end{array}$ & $\begin{array}{l}\mathrm{P} \\
\mathrm{mg} / \mathrm{kg}\end{array}$ & $\begin{array}{l}\mathrm{K} \\
\mathrm{cmol} / \mathrm{kg}\end{array}$ & $\begin{array}{l}\mathrm{Ca} \\
\mathrm{cmol} / \mathrm{kg}\end{array}$ & $\begin{array}{l}\mathrm{Mg} \\
\mathrm{cmol} / \mathrm{kg}\end{array}$ & $\begin{array}{l}\mathrm{Na} \\
\mathrm{cmol} / \mathrm{kg}\end{array}$ & $\begin{array}{l}\mathrm{Mn} \\
\mathrm{mg} / \mathrm{kg}\end{array}$ & $\begin{array}{l}\mathrm{Cu} \\
\mathrm{mg} / \mathrm{kg}\end{array}$ & $\begin{array}{l}\mathrm{Fe} \\
\mathrm{mg} / \mathrm{kg}\end{array}$ & $\begin{array}{l}\mathrm{Zn} \\
\mathrm{mg} / \mathrm{kg}\end{array}$ & $\begin{array}{l}\mathrm{pH} \\
\left(\mathrm{H}_{2} \mathrm{O}\right)\end{array}$ \\
\hline 60 & 1 & $18.3 \mathrm{a}$ & $2.2 \mathrm{a}$ & $6.00 \mathrm{~m}$ & $0.95 f$ & $2.30 \mathrm{a}$ & $2.24 \mathrm{ef}$ & $1.82 \mathrm{ef}$ & $18.19 \mathrm{~d}$ & $3.10 \mathrm{~cd}$ & $257 \mathrm{e}$ & 1.11a-d & $7.03 \mathrm{~b}-\mathrm{d}$ \\
\hline 60 & 2 & $16.9 \mathrm{ab}$ & $1.4 \mathrm{~b}$ & $9.62 \mathrm{k}$ & $0.95 f$ & $1.7 \mathrm{e}$ & $2.36 \mathrm{~b}-\mathrm{f}$ & $1.96 \mathrm{de}$ & $14.69 \mathrm{~g}$ & $2.3 \mathrm{f}-\mathrm{h}$ & $198 \mathrm{j}$ & $0.90 \mathrm{fg}$ & $6.91 \mathrm{~cd}$ \\
\hline 60 & 3 & $15.5 b c$ & $1.2 b$ & $5.93 \mathrm{~m}$ & $0.97 \mathrm{f}$ & $1.85 \mathrm{c}$ & $2.36 b-f$ & $1.81 \mathrm{ef}$ & $11.80 \mathrm{~m}$ & $2.3 \mathrm{f}-\mathrm{h}$ & $210 \mathrm{i}$ & $0.93 \mathrm{e}-\mathrm{g}$ & $7.09 b-d$ \\
\hline 60 & 4 & $17.0 \mathrm{ab}$ & $1.1 \mathrm{~b}$ & 9.191 & $0.73 \mathrm{~g}$ & $1.7 \mathrm{e}$ & $2.37 \mathrm{~b}-\mathrm{f}$ & $1.70 \mathrm{f}$ & $11.10 \mathrm{n}$ & $2.20 \mathrm{f}-\mathrm{h}$ & $158 \mathrm{~m}$ & $0.62 \mathrm{i}$ & $6.9 \mathrm{~cd}$ \\
\hline 120 & 1 & $16.8 \mathrm{ab}$ & $1.4 b$ & $10.13 \mathrm{j}$ & $1.50 \mathrm{~cd}$ & $1.85 \mathrm{c}$ & $2.44 b-d$ & $2.00 \mathrm{c}-\mathrm{e}$ & $18.59 \mathrm{c}$ & $3.50 \mathrm{c}$ & $249 f$ & $1.00 \mathrm{~d}-\mathrm{f}$ & $6.88 \mathrm{~cd}$ \\
\hline 120 & 2 & $16.9 \mathrm{ab}$ & $1.3 b$ & $10.12 \mathrm{j}$ & $1.43 \mathrm{~d}$ & $1.7 \mathrm{e}$ & $2.46 b c$ & $2.14 b-d$ & $14.10 \mathrm{~h}$ & $2.5 \mathrm{e}-\mathrm{g}$ & $212 \mathrm{i}$ & $1.16 \mathrm{a}-\mathrm{c}$ & 7.18a-c \\
\hline 120 & 3 & $12.4 \mathrm{ef}$ & $1.2 b$ & $9.74 \mathrm{k}$ & $1.07 \mathrm{ef}$ & $2.15 b$ & $2.71 \mathrm{a}$ & $1.74 \mathrm{f}$ & $13.69 \mathrm{i}$ & 2.6.0ef & $256 \mathrm{e}$ & $1.13 \mathrm{a}-\mathrm{d}$ & 7.40ab \\
\hline 120 & 4 & $16.0 b c$ & $1.7 b$ & $10.57 \mathrm{i}$ & $1.19 \mathrm{e}$ & $2.30 \mathrm{a}$ & $2.80 \mathrm{a}$ & $1.81 \mathrm{ef}$ & $12.80 \mathrm{k}$ & $2.83 \mathrm{de}$ & $221 \mathrm{~h}$ & $0.71 \mathrm{hi}$ & $6.97 b-d$ \\
\hline 180 & 1 & $18.2 \mathrm{a}$ & $1.5 b$ & $12.54 \mathrm{e}$ & $1.62 b c$ & $1.5 \mathrm{~h}$ & $1.98 \mathrm{~g}$ & $2.07 b-d$ & $18.09 \mathrm{~d}$ & 2.6ef & $218 \mathrm{~h}$ & $0.93 \mathrm{e}-\mathrm{g}$ & $6.97 b-d$ \\
\hline 180 & 2 & $13.3 \mathrm{de}$ & $1.1 \mathrm{~b}$ & $11.37 \mathrm{~g}$ & $1.41 \mathrm{~d}$ & $1.6 \mathrm{~g}$ & $2.44 b-d$ & $2.14 b-d$ & $15.89 \mathrm{e}$ & $2.83 \mathrm{de}$ & $288 b$ & $1.25 \mathrm{a}$ & 7.17a-d \\
\hline 180 & 3 & $16.9 \mathrm{ab}$ & $1.2 b$ & $11.01 \mathrm{~h}$ & $1.38 \mathrm{~d}$ & $1.8 \mathrm{~d}$ & $2.50 \mathrm{~b}$ & $2.00 \mathrm{c}-\mathrm{e}$ & $13.20 \mathrm{j}$ & 2.90de & $193 \mathrm{k}$ & $1.19 \mathrm{ab}$ & $7.35 \mathrm{ab}$ \\
\hline 180 & 4 & $15.8 b c$ & $1.1 \mathrm{~b}$ & $12.13 \mathrm{f}$ & $1.16 \mathrm{e}$ & $1.65 \mathrm{f}$ & $2.23 \mathrm{f}$ & $1.66 \mathrm{fg}$ & $12.69 \mathrm{k}$ & $2.60 \mathrm{ef}$ & $229 \mathrm{~g}$ & $0.63 \mathrm{i}$ & 7.11b-d \\
\hline 240 & 1 & $16.6 \mathrm{ab}$ & $1.4 \mathrm{~b}$ & $14.69 b$ & $2.06 \mathrm{a}$ & $2.30 \mathrm{a}$ & $2.28 \mathrm{~d}-\mathrm{f}$ & $2.44 \mathrm{a}$ & $22.46 a$ & $4.70 \mathrm{a}$ & $336 a$ & $1.10 \mathrm{~b}-\mathrm{d}$ & $7.12 b-d$ \\
\hline 240 & 2 & $16.1 b c$ & $1.1 \mathrm{~b}$ & $14.05 \mathrm{c}$ & $1.72 b$ & $1.35 \mathrm{i}$ & $2.08 \mathrm{~g}$ & $2.18 b c$ & $15.59 \mathrm{f}$ & $2.30 \mathrm{f}-\mathrm{h}$ & $277 \mathrm{~cd}$ & $0.82 \mathrm{gh}$ & 7.18a-d \\
\hline 240 & 3 & $14.5 \mathrm{~cd}$ & $1.5 b$ & $16.38 \mathrm{a}$ & $1.99 \mathrm{a}$ & $1.5 \mathrm{~h}$ & $2.4 \mathrm{~b}-\mathrm{e}$ & $2.25 b$ & $19.50 \mathrm{~b}$ & $4.10 \mathrm{~b}$ & $273 d$ & $1.03 \mathrm{c}-\mathrm{e}$ & 7.29a-c \\
\hline 240 & 4 & 11.1f & $1.3 b$ & $12.84 \mathrm{~d}$ & $1.60 b c$ & $1.3 \mathrm{j}$ & $2.52 b$ & $1.67 \mathrm{fg}$ & $18.19 d$ & 2.1gh & $278 \mathrm{c}$ & $0.71 \mathrm{hi}$ & 7.58a \\
\hline Control & & $16.2 b$ & $1.2 \mathrm{~b}$ & $11.33 \mathrm{~g}$ & $0.74 \mathrm{~g}$ & $1.7 \mathrm{e}$ & $2.33 c-f$ & $1.50 \mathrm{~g}$ & 7.950 & $1.97 \mathrm{~h}$ & $120 n$ & $0.81 \mathrm{gh}$ & $6.75 \mathrm{~d}$ \\
\hline
\end{tabular}

Means in a column followed by the same letter are not significantly different according to DMRT $(p=0.05)$ 
Frequency of CE application to the soil significantly increased soil $\mathrm{Ca}$ by $2-17 \%$ when applied once, twice or four times compared to the control treatment. In contrast, three applications of CE significantly reduced soil Ca by $6 \%$ compared to the control treatment. Two applications of CE to the soil significantly increased soil $\mathrm{Mg}$ by $7 \%$ compared to the control treatment while four applications of $\mathrm{CE}$ significantly reduced soil $\mathrm{Mg}$ by $4 \%$.

The application of $\mathrm{CE}$ to the potted soil at one to four times significantly increased the soil $\mathrm{Na}, \mathrm{K}, \mathrm{Cu}, \mathrm{Fe}$ and $\mathrm{Mn}$ compared to the control treatment. Soil $\mathrm{Fe}$ and $\mathrm{Mn}$ increased with increasing frequency of CE application. In contrast, the response of soil $\mathrm{Na}, \mathrm{K}$ and $\mathrm{Cu}$ to increasing frequency of $\mathrm{CE}$ application had no clear trend.

Two to four applications of CE to the soil significantly increased soil $\mathrm{Zn}$ by $26-30 \%$ while application of CE once resulted in significant reduction of $23 \%$ compared to the control treatment. The soil $\mathrm{pH}$ increased significantly $(p<0.05)$ when CE was applied one to four times by $4-8 \%$ compared to the control treatment. However, the response of soil $\mathrm{pH}$ to increasing frequency of $\mathrm{CE}$ application had no clear trend.

\section{Interaction between CE concentration and frequency of application on soil mineral elements}

The interaction between CE concentration and frequency of application was significant on all the soil mineral elements analysed (Table 4). However, the concentrations of SOC, N, Na, K, Mn, Cu and Fe were not significantly reduced by the interaction between $\mathrm{CE}$ concentration and frequency of application compared to the control treatment. Cassava effluent concentration of $240 \mu \mathrm{g}$ $\mathrm{CN} / \mathrm{kg}$ soil applied once had no mineral element that was significantly reduced compared to the control treatment. In contrast, other interactions of $\mathrm{CE}$ concentration and frequency of application significantly reduced the concentration of one or more mineral elements.

Cassava effluent concentration of 180 or $240 \mu \mathrm{g} \mathrm{CN} / \mathrm{kg}$ soil applied twice or four times significantly reduced soil Ca. Similarly, $240 \mu \mathrm{g} \mathrm{CN} / \mathrm{kg}$ soil applied thrice also did the same. Four-time application of $240 \mu \mathrm{g} \mathrm{CN} / \mathrm{kg}$ soil had the least soil Ca. It was $24 \%$ lesser than the control treatment. The concentration of $\mathrm{Mg}$ was significantly lesser in potted soil treated twice with $240 \mu \mathrm{g} \mathrm{CN} / \mathrm{kg}$ soil and $180 \mu \mathrm{g} \mathrm{CN} / \mathrm{kg}$ soil applied once compared to the control treatment. The highest $\mathrm{Mg}$ reduction resulted from $180 \mu \mathrm{g} \mathrm{CN} / \mathrm{kg}$ soil applied once $(1.98 \mathrm{cmol} / \mathrm{kg})$. It was $15 \%$ lesser compared to the control treatment $(2.33 \mathrm{cmol} / \mathrm{kg})$.
Soil treated with CE concentration of 60 or $120 \mu \mathrm{g}$ $\mathrm{CN} / \mathrm{kg}$ soil in all the application frequencies had significantly lesser available $\mathrm{P}$ than the control treatment. Similarly, soil treated with $180 \mu \mathrm{g} \mathrm{CN} / \mathrm{kg}$ soil thrice had significantly lesser available $\mathrm{P}$ compared to the control treatment. Three applications of $60 \mu \mathrm{g} \mathrm{CN} / \mathrm{kg}$ soil had the highest $\mathrm{P}$ reduction $\left(5.93 \mathrm{mg} \mathrm{kg}^{-1}\right)$. It was $48 \%$ lesser than the control treatment $\left(11.33 \mathrm{mg} \mathrm{kg}^{-1}\right)$. Soil treated four times with $\mathrm{CE}$ of 60 or $180 \mu \mathrm{g} \mathrm{CN} / \mathrm{kg}$ soil had $\mathrm{Zn}$ that was significantly lesser than the control treatment. Four applications of $60 \mu \mathrm{g} \mathrm{CN} / \mathrm{kg}$ soil had the highest $\mathrm{Zn}$ reduction of $27 \%$ compared to the control treatment.

The interaction between $\mathrm{CE}$ concentration and frequency of application did not significantly reduce soil $\mathrm{pH}$. In contrast, soil treated with $\mathrm{CE}$ of $120 \mu \mathrm{g} \mathrm{CN} / \mathrm{kg}$ soil twice or thrice, $180 \mu \mathrm{g} \mathrm{CN} / \mathrm{kg}$ soil applied thrice and $240 \mu \mathrm{g}$ $\mathrm{CN} / \mathrm{kg}$ soil applied thrice or four times resulted in soil $\mathrm{pH}$ $\left(\mathrm{H}_{2} \mathrm{O}\right)$ that were significantly higher than the control treatment.

Soil treated once with CE of $60 \mu \mathrm{g} \mathrm{CN} / \mathrm{kg}$ soil had the highest SOC $(1.83 \%)$, total $\mathrm{N}(0.22 \%)$, and available $\mathrm{Ca}$ $(2.30 \mathrm{cmol} / \mathrm{kg})$ amongst the treatment interactions. These increased by $13 \%, 83 \%$ and $35 \%$ above that of the control treatment, respectively. Similarly, soil treated once with CE of $240 \mu \mathrm{g} \mathrm{CN} / \mathrm{kg}$ soil had the highest $\mathrm{Na}, \mathrm{K}, \mathrm{Mn}, \mathrm{Cu}$ and $\mathrm{Fe}$ which were $83 \%, 178 \%, 183 \%, 139 \%$, and $180 \%$ above those of the control treatment, respectively. Four CE applications of $120 \mu \mathrm{g} \mathrm{CN} / \mathrm{kg}$ soil resulted in the highest soil $\mathrm{Mg}(2.80 \mathrm{cmol} / \mathrm{kg})$. It was $20 \%$ more than the control treatment. The highest available $\mathrm{P}$ resulted from soil treated thrice with CE of $240 \mu \mathrm{g} \mathrm{CN} / \mathrm{kg}$ soil $\left(16.38 \mathrm{mg} \mathrm{kg}^{-1}\right)$. It was $45 \%$ more than the control treatment. Two CE applications of $180 \mu \mathrm{g} \mathrm{CN} / \mathrm{kg}$ soil resulted in soil with the highest $\mathrm{Zn}$ $\left(1.25 \mathrm{mg} \mathrm{kg}^{-1}\right)$. It was $54 \%$ more than the control treatment.

Table 5: Effect of $C E$ concentration on soil microorganisms

\begin{tabular}{ccc}
\hline $\begin{array}{l}\text { CE } \\
(\boldsymbol{\mu g ~ C N} / \mathbf{~ k g})\end{array}$ & $\begin{array}{l}\text { Bacteria } \\
\left.\text { (NA-X10 }^{\mathbf{c}} \mathbf{c f u} / \mathbf{m g}\right)\end{array}$ & $\begin{array}{l}\text { Fungi } \\
\left.\text { (PDA-X 10 }^{7} \mathbf{c f u} / \mathbf{m g}\right)\end{array}$ \\
\hline 60 & $29.8 \mathrm{c}$ & $6.0 \mathrm{~b}$ \\
120 & $25.4 \mathrm{c}$ & $30.9 \mathrm{a}$ \\
180 & $48.4 \mathrm{~b}$ & $27.2 \mathrm{a}$ \\
240 & $50.9 \mathrm{~b}$ & $27.9 \mathrm{a}$ \\
Control & $125.7 \mathrm{a}$ & $28.3 \mathrm{a}$ \\
\hline
\end{tabular}

Means in a column followed by the same letter are not significantly different according to DMRT $(\mathrm{P}=0.05)$

Effect of CE concentration and frequency of CE application on soil microorganisms

The bacteria identified in the control treatment are Bacillus, Pseudomonas, Micrococcus, Citrobacter and 
Alcaligenes species while the fungi are Aspergillus, Fusarium, Rhizopus and Trichoderma species. Cassava effluent applied at all the concentrations to the soil resulted in significantly lesser number of bacteria compared to the untreated soil (Table 5). Soil treated with 120,180 or 240 $\mu \mathrm{g} \mathrm{CN} / \mathrm{kg}$ soil had fungi counts that were not significantly different $(p<0.05)$ from each other and that were comparable to control treatment. However, CE application at $60 \mu \mathrm{g} \mathrm{CN} / \mathrm{kg}$ soil had fungi count that was significantly lesser than other treatments.

All the frequencies of $\mathrm{CE}$ application significantly reduced $(p<0.05)$ soil bacterial count compared to the control treatment (Table 6). Soil treated two times had the least bacteria count $\left(26.08 \times 10^{9} \mathrm{cfu} / \mathrm{mg}\right)$ while control experiment had the highest (125.67 X $\left.10^{9} \quad \mathrm{cfu} / \mathrm{mg}\right)$. Frequency of CE application did not have significant effect on fungi population.

Table 6: Effect of frequency of CE application on soil microorganisms

\begin{tabular}{ccc}
\hline Frequency & $\begin{array}{l}\text { Bacteria } \\
\text { (NA -X10 } \mathbf{~ c f u} / \mathbf{m g})\end{array}$ & $\begin{array}{l}\text { Fungi } \\
\left.\text { (PDA }-X \mathbf{~ 1 0}^{\mathbf{7}} \mathbf{c f u} / \mathbf{m g}\right)\end{array}$ \\
\hline 1 & $40.8 \mathrm{c}$ & 21.9 \\
2 & $26.1 \mathrm{~d}$ & 23.8 \\
3 & $41.5 \mathrm{bc}$ & 27.0 \\
4 & $46.3 \mathrm{~b}$ & 19.3 \\
Control & $125.7 \mathrm{a}$ & 28.3 \\
\hline
\end{tabular}

Means in a column followed by the same letter are not significantly different according to DMRT $(\mathrm{P}=0.05)$.

Interaction between $\mathrm{CE}$ concentration and frequency of application had significant influence $(p<0.05)$ on bacteria and fungi population (Table 7). Interaction between $\mathrm{CE}$ concentration and frequency of application significantly reduced $(p<0.05)$ soil bacterial count. Soil treated once with $\mathrm{CE}$ of $180 \mu \mathrm{g} \mathrm{CN} / \mathrm{kg}$ soil had the least culturable bacteria $\left(11.67 \times 10^{9} \mathrm{cfu} / \mathrm{mg}\right)$. The fungal count in soil treated twice with $\mathrm{CE}$ of $60 \mu \mathrm{g} \mathrm{CN} / \mathrm{kg}$ soil and $180 \mu \mathrm{g} \mathrm{CN} / \mathrm{kg}$ soil applied thrice increased significantly compared to the untreated soil. Contrarily, soil treated once with $\mathrm{CE}$, irrespective of concentration, resulted in significantly reduced fungal population compared to the untreated soil. Also, $240 \mu \mathrm{g}$ $\mathrm{CN} / \mathrm{kg}$ soil applied thrice and $60 \mu \mathrm{g} \mathrm{CN} / \mathrm{kg}$ soil applied four times resulted in reduced fungal count.

\section{Discussion}

\section{Effect of CE chemigation on soil mineral elements}

The change in the concentrations of SOC, Mg, Na, K, $\mathrm{P}, \mathrm{Mn}, \mathrm{Cu}, \mathrm{Fe}$ and $\mathrm{Zn}$ in the soil upon the application of $\mathrm{CE}$ for weed control could be attributed to the presence of these elements in $\mathrm{CE}$ and their resultant reaction in the soil. This corroborates earlier studies (Osakwe and Akpoveta, 2012; Orhue et al., 2014) that reported the soil nutrient modifying ability of CE.

The total soil $\mathrm{N}$, that was not significantly influenced by $\mathrm{CE}$ of $60,120,180$ and $240 \mu \mathrm{g} \mathrm{CN} / \mathrm{kg}$ soil, is an indication that these weed control concentrations are not good sources of $\mathrm{N}$ to the soil. The amount of $\mathrm{N}$ present in these $\mathrm{CE}$ concentrations was plausibly not consequential to influence the total soil $\mathrm{N}$. This finding does not agree with the reports of Osakwe and Akpoveta (2012) and Nwakaudu et al. (2012) that CE added to the soil significantly altered the soil nitrogen concentration. Difference in the CE concentrations used in these studies may be responsible for this disparity.

Table 7: Interaction between $\mathrm{CE}$ concentration and frequency of application on soil microorganisms

\begin{tabular}{cccc}
\hline $\begin{array}{l}\text { CE } \\
(\boldsymbol{\mu g} \mathbf{C N} / \mathbf{k g})\end{array}$ & Freq. & $\begin{array}{l}\text { Bacteria } \\
\text { (NA-X10 }^{9} \\
\text { (fu/mg) }\end{array}$ & $\begin{array}{l}\text { Fungi } \\
\text { (PDA-X 10 }^{7} \\
\text { cfu/mg) }\end{array}$ \\
\hline 60 & 1 & $58.7 \mathrm{~d}$ & $4.7 \mathrm{i}$ \\
60 & 2 & $21.0 \mathrm{~h}$ & $55.0 \mathrm{a}$ \\
60 & 3 & $39.3 \mathrm{ef}$ & $17.7 \mathrm{e}-\mathrm{i}$ \\
60 & 4 & $44.0 \mathrm{e}$ & $10.3 \mathrm{f}-\mathrm{i}$ \\
120 & 1 & $28.7 \mathrm{gh}$ & $7.3 \mathrm{~h}-\mathrm{i}$ \\
120 & 2 & $34.3 \mathrm{fg}$ & $23.0 \mathrm{c}-\mathrm{g}$ \\
120 & 3 & $21.0 \mathrm{~h}$ & $33.0 \mathrm{~cd}$ \\
120 & 4 & $20.3 \mathrm{~h}$ & $31.7 \mathrm{c}-\mathrm{e}$ \\
180 & 1 & $11.7 \mathrm{i}$ & $3.3 \mathrm{i}$ \\
180 & 2 & $23.3 \mathrm{~h}$ & $24.0 \mathrm{c}-\mathrm{f}$ \\
180 & 3 & $97.7 \mathrm{c}$ & $48.0 \mathrm{ab}$ \\
180 & 4 & $33.3 \mathrm{fg}$ & $32.7 \mathrm{~cd}$ \\
240 & 1 & $20.3 \mathrm{~h}$ & $8.7 \mathrm{~g}-\mathrm{i}$ \\
240 & 2 & $23.0 \mathrm{~h}$ & $21.7 \mathrm{~d}-\mathrm{h}$ \\
240 & 3 & $35.7 \mathrm{e}-\mathrm{g}$ & $10.0 \mathrm{f}-\mathrm{i}$ \\
240 & 4 & $106.0 \mathrm{~b}$ & $37.0 \mathrm{bc}$ \\
Control & & $125.7 \mathrm{a}$ & $28.3 \mathrm{c}-\mathrm{e}$ \\
\hline
\end{tabular}

Means in a column followed by the same letter are not significantly different according to DMRT $(\mathrm{P}=0.05)$

The decrease observed in SOC upon CE addition of 240 $\mu \mathrm{g} \mathrm{CN} / \mathrm{kg}$ soil could be a pointer to increase in decomposition activity of soil microbes, thus causing sorption of organic carbon into their cell, thereby reducing SOC. However, the reduced SOC from the addition of 240 $\mu \mathrm{g} \mathrm{CN} / \mathrm{kg}$ soil was still above the critical limit of SOC composition in tropical soils (Ravikumar and Somashekar, 
2013). Hence, application of this CE concentration for weed control may not lead to serious SOC loss.

The reduction in available soil $\mathrm{P}$ upon $\mathrm{CE}$ addition of 60 and $120 \mu \mathrm{g} \mathrm{CN} / \mathrm{kg}$ soil and its increase upon the addition of 180 and $240 \mu \mathrm{g} \mathrm{CN} / \mathrm{kg}$ soil had a reverse trend with $\mathrm{Ca}$ with reference to the control treatment. This suggests that the concentrations of these mineral elements in the soil are inversely related upon the addition of $\mathrm{CE}$ concentration range used in this study. Increase in the concentration of $\mathrm{Ca}$ can cause free $\mathrm{Ca}$ to form complexes with $\mathrm{P}$, thereby reducing its concentration (Stewart and Tiessen, 1987). It is opined that the $\mathrm{Ca}$ concentration in the soil that increased upon the application of 60 and $120 \mu \mathrm{g} \mathrm{CN} / \mathrm{kg}$ soil may be due to the richness of this mineral element in the effluent while its reduction may be due to the displacement reaction by the increasing $\mathrm{Na}$ concentration.

The significant increase in soil $\mathrm{Na}, \mathrm{K}$ and $\mathrm{Mg}$ with the addition of $\mathrm{CE}$ concentrations disagrees with the findings of Eze and Onyilide (2015) that reported that these mineral elements decreased when CE was applied to soil. The observed increase in the concentration of trace elements such as $\mathrm{Mn}, \mathrm{Cu}, \mathrm{Fe}$, and $\mathrm{Zn}$ upon the addition of $\mathrm{CE}$ concentrations to the soil for weed control had also been reported in previous studies (Nwakaudu et al., 2012; Osakwe and Akpoveta, 2012; Igbinosa and Igiehon, 2015). Hence, the adoption of CE concentrations used in this study for weed control is only safe where the permissible limits of these trace elements in the soil will not be exceeded.

The increase in the soil $\mathrm{pH}$ resulting from the addition of $\mathrm{CE}$ was an indication that the $\mathrm{CE}$ concentrations used in this study reduced the acidity level of the soil. Similarly, Chinyere et al. (2018) reported that dumpsite of CE had increased soil $\mathrm{pH}$ over control soil samples. However, this finding does not agree with some previous studies that reported that addition of $\mathrm{CE}$ to the soil decreased its $\mathrm{pH}$ (Osakwe and Akpoveta, 2012; Ehiagbonare et al., 2009). The increase in soil $\mathrm{pH}$ that resulted from the addition of CE to soil in this study could be due to the associated increase in soil $\mathrm{Na}$ and $\mathrm{K}$. The presence of base forming ions increases the $\mathrm{pH}$ of the soil (Mitra and Shanker, 1957; Lakshmi et al., 2019).

\section{Effect of frequency of CE chemigation on soil mineral elements}

Findings from this study indicate that the frequency of CE application influenced soil nutrients. This could be of an advantage when the nutrients are improved. However, the significant reduction of some nutrient elements could be a concern if it can hinder the growth of crops when applied for weed control. For instance, reduction in SOC when CE was applied once or twice could be adduced to immobilization caused by increased activities of microorganism (Xu et al., 2018). CE applied thrice provided the organic carbon requirement of the associated microorganism. Hence, the resulted SOC was not significantly influenced compared to the control treatment. However, four applications of $\mathrm{CE}$ provided excess organic carbon that was more than what the associated microorganism required, hence this resulted in increase in the SOC. The implication of this is that CE applied once or twice for weed control may temporarily reduce SOC of the treated soil.

The total $\mathrm{N}$ content of the soil was not significantly influenced by CE applied once, twice or thrice indicating that these $\mathrm{CE}$ application frequencies for weed control does not have the additional advantage of improving the $\mathrm{N}$ content of the soil whereas CE applied four times does. The increase observed in soil total $\mathrm{N}$ with frequency of $\mathrm{CE}$ application in this study agrees with the report of Osakwe and Akpoveta (2012) who found CE capable of increasing soil N.

Increase in soil $\mathrm{Na}, \mathrm{K}, \mathrm{Mn}, \mathrm{Cu}$ and $\mathrm{Fe}$ due to the frequency of $\mathrm{CE}$ application suggests that $\mathrm{CE}$ applied one to four times for weed control could enhance these elements in the soil. Hence, the use of these CE application frequencies for weed control should take the inherent concentration of these trace nutrients into consideration to avoid toxicity to crops.

The reduction in $\mathrm{Ca}$ concentration that resulted from $\mathrm{CE}$ applied thrice coincided with the peak concentration of $\mathrm{Na}$. Therefore, it is opined that the increase in the Na concentration was responsible for the significant decrease in $\mathrm{Ca}$ concentration. The soil $\mathrm{pH}$ that increased significantly when $\mathrm{CE}$ was applied one to four times could be due to the increase in the $\mathrm{Na}$ and $\mathrm{K}$ content of the soil (Lakshmi et al., 2019).

\section{Interaction between CE concentration and frequency of chemigation on soil mineral elements}

Cassava effluent of $240 \mu \mathrm{g} \mathrm{CN} / \mathrm{kg}$ soil applied once may be ideal for weed control based on soil consideration since none of the mineral elements of this treatment was significantly reduced compared to the control treatment. However, the decrease in soil mineral elements by the interaction between $\mathrm{CE}$ concentration and frequency of application should not necessarily debar its adoption for weed control if the decrease is temporary and is not capable of nutrient deficiency in crop or growth retardation.

\section{Effect of CE concentration and frequency of chemigation on soil microorganisms}

Reduction in soil bacterial count due to concentration and frequency of application of CE found has also been reported by Igbinosa and Igiehon, (2015). This has 
implication on soil nutrient immobilization and availability as it had been established that Bacillus, Pseudomonas, and Alcaligenes species contribute to soil nutrient availability (Ipek et al., 2014; Meena et al., 2016; Saha et al., 2016).

The $\mathrm{CE}$ of $60 \mu \mathrm{g} \mathrm{CN} / \mathrm{kg}$ soil, that had significantly lesser fungal count compared to other treatments, may be due to the significantly lesser $P$ found in the treatment. This agrees with the report of del Mar Alguacil et al. (2010) that addition of low doses of $\mathrm{P}$ could increase the colonization of some fungi. However, fungal count that was not significantly different in the control treatment and the potted soil treated with $\mathrm{CE}$ one to four times may be due to the inability of $\mathrm{CE}$ to alter the soil $\mathrm{pH}$ range from neutral to acidic that is favorable for fungi (Abubakar et al., 2013).

The interactions between $\mathrm{CE}$ concentration and frequency of application that altered fungal count both positively and negatively did not exhibit any distinct trend when compared with the soil chemical properties. Hence, it is opined that the differential response of fungi genera to the resulting soil chemical properties may be responsible for this (Sieverding and Howeler, 1985). The interaction effect between CE concentration and frequency of application that resulted in reduced fungal population may inhibit phosphate-solubilizing role of Aspergillus and Rhizopus species (Sharma et al., 2013) and the biocontrol activities of Trichoderma species (Commatteo et al., 2019).

\section{Conclusion}

The application of CE to the soil for weed control has a significant modifying effect on the soil nutrient levels and the population of microorganisms therein. Hence, its adoption for weed control requires the understanding of its influence on soil chemical and biological properties.

\section{References}

Abubakar, A., H. Suberu, I. Bello, R. Abdulkadir, O. Daudu, and A. Lateef. 2013. Effect of pH on mycelial growth and sporulation of Aspergillus parasiticus. Journal of Plant Sciences 1 (4): 64-67.

Adabie, D.F. 2015. Occupational health hazards associated with gari production and the possible environmental effects of the resultant effluent. Doctoral dissertation, University of Ghana. $91 \mathrm{p}$.

Agiriga, A.N. and M.O. Iwe. 2016. Optimization of chemical properties of cassava varieties harvested at different times using response surface methodology. American Journal of Advanced Food Science and Technology 4 (1) :10-21.

Akadiri M.B., O.P Ayodele, R.D. Aladesanwa. 2017. Evaluation of selected post-emergence herbicides for weed management in maize at different agroecological zones of Nigeria. World Journal of Agricultural Research 5 (5): 258-264

Aladesanwa, R.D. and O.P. Ayodele. 2011. Weed control in the long-fruited jute (corchorus olitorius 1.) with paraquat alone and in combination with glyphosate at varying doses including their effects on its growth, development, yield and nutritional quality in southwestern Nigeria. Applied Tropical Agriculture 15: (1\&2): 65-75.

Arif, M., Z.A. Cheema, A. Khaliq, and A. Hassan. 2015. Organic weed management in wheat through allelopathy. International Journal of Agriculture and Biology 17 (1):127-134

APHA - American Public Health Association. 1995. Standard Methods for the Examination of Water and Wastewater. $17^{\text {th }}$ Ed. American Public Health Association, Washington. $2198 \mathrm{p}$.

Bajwa, A., G. Mahajan, and B. Chauhan. 2015. Nonconventional weed management strategies for modern agriculture. Weed Science 63 (4): 723-747.

Barnett, H.L. and B.B. Hunter. 1972. Illustrated genera of imperfect fungi. 3rd Ed., Burgess Publishing Co., Minneapolis. $241 \mathrm{p}$.

Black, C.A, 1965. Methods of Soil Analysis. Part I, American Society of Agronomy. Madison, Wisconsin, USA. $1572 \mathrm{p}$.

Bray, R.H and L.T Kurtz. 1945. Determination of total, organic and available forms of phosphorus in soils. Soil Science 59: 39-45.

Chinyere, G., C. Nwaogwugwu, K. Akatobi and K. Osuocha. 2018. Influence of cassava mill effluent (CME) dumping on soil physicochemical parameters and selected plant nutrients in Uturu, Abia State Nigeria. Global Scientific Journals 6 (1): 260-274.

Commatteo, J.G., V.F. Consolo, P.A. Barbieri and F. Covacevich. 2019. Indigenous arbuscular mycorrhiza and Trichoderma from systems with soybean predominance can improve tomato growth. Soil and Environment 38 (2): 151-161

del Mar Alguacil, M., Z. Lozano, M. Campoy and A. Roldán. 2010. Phosphorus fertilisation management modifies the biodiversity of AM fungi in a tropical savanna forage system. Soil Biology and Biochemistry 42 (7): 1114-1122.

Ehiagbonare, J.E., S.A. Enabulele, B.B. Babatunde and R. Adjarhore. 2009. Effect of cassava effluents on Okada denizens. Scientific Research and Essay 4 (4): 310 313.

Eze, V.C. and D.M. Onyilide. 2015. Microbiological and physiochemical characteristics of soil receiving cassava 
effluent in Elele, Rivers State, Nigeria. Journal of Applied \& Environmental Microbiology 3 (1) : 20-24.

Fayinminnu, O.O., O.O. Fadina and A.A. Adedapo. 2013. Screening of chemical composition of crude water extract of different cassava varieties. Annals of West Zuniversity of Timisoara, Ser. Biology 16 (1): 61-66.

Gaupp-Berghausen, M., M. Hofer, B. Rewald and J.G. Zaller. 2015. Glyphosate-based herbicides reduce the activity and reproduction of earthworms and lead to increased soil nutrient concentration. Scientific Reports 5 (12886) : 1-9

George, D. and P. Mallery. 2016. IBM SPSS statistics 23 step by step: A simple guide and reference. 14th Ed, Routledge, New York. 400 p.

Igbinosa, E.O. and O.N. Igiehon. 2015. The impact of cassava effluent on the microbial and physicochemical characteristics on soil dynamics and structure. Jordan Journal of Biological Sciences 8(2), 107 - 112.

IITA-International Institute of Tropical Agriculture. 1979. Selected Methods for Soil and Plant Analysis. Manual series No. 1. International Institute of Tropical Agriculture Ibadan, Nigeria, 3-12.

Ipek, M., L. Pirlak, A. Esitken, M. Figen Dönmez, M. Turan and F. Sahin. 2014. Plant growth-promoting rhizobacteria (PGPR) increase yield, growth and nutrition of strawberry under high-calcareous soil conditions. Journal of Plant Nutrition 37(7): 990-1001.

Jabran, K., G. Mahajan, V. Sardana and B.S. Chauhan. 2015. Allelopathy for weed control in agricultural systems. Crop Protection 72: 57-65.

Jackson M.L. 1962. Soil Chemical and Particle Size Analysis. Prentice Hall, Inc. Eagle wood Cliffs, New York. 498 p.

Kjeldahl, J. 1983. The Kjeldahl determination of nitrogen: retrospect and prospect. Trends in Analytical Chemistry 13(4): 138-144

Kremer, R. and T. Souissi. 2001. Cyanide production by rhizobacteria and potential for suppression of weed seedling growth. Current Microbiology 43(3): 182-186.

Kumar, A., I. Bahadur, B.R. Maurya, R. Raghuwanshi, V.S. Meena, D.K. Singh and J. Dixit. 2015. Does a plant growth-promoting rhizobacteria enhance agricultural sustainability. Journal of Pure and Applied Microbiology 9 (1): 715-724.

Kumar, A., B.R. Maurya, R. Raghuwanshi, V.S. Meena and M.T. Islam. 2017. Co-inoculation with Enterobacter and Rhizobacteria on yield and nutrient uptake by wheat (Triticum aestivum L.) in the alluvial soil under indo-gangetic plain of India. Journal of Plant Growth Regulation 36 (3): 608-617.

Lakshmi, P.D., M.S. Nagaraja, S. Meti, R. Suma, C.N. Pallavi and A.E. Kondi. 2019. Evaluation of sodicity indices for non-saline sodic soils of Ramthal Micro Irrigation Project Area of UKP and their associated risks for horticultural crops. International Journal of Current Microbiology and Applied Science 8 (2): 349357.

Masiol, M., B. Giannì, and M. Prete. 2018. Herbicides in river water across the northeastern Italy: occurrence and spatial patterns of glyphosate, aminomethyl phosphonic acid, and glufosinate ammonium. Environmental Science and Pollution Research 25 (24): 24368-24378

Meena, V.S., B.R. Maurya, S.K. Meena, R.K. Meena, A. Kumar, J.P. Verma, and N.P. Singh. 2016. Can Bacillus species enhance nutrient availability in agricultural soils?. p 367-395. In : Bacilli and Agrobiotechnology. M. Islam, M. Rahman, P. Pandey, C. Jha and A. Aeron (eds.). Springer, Cham.

McLay, L.D and A.D. Robson. 1992. The effect of chlorsulfuron and diclofop-methyl on the uptake and utilization of zinc by wheat. Australian Journal of Agricultural Research 43 (1): 59-65.

Mitra, S. and H. Shanker. 1957. Formation of alkali soils by neutral salt solutions. Soil Science and Plant Nutrition 3 (1): 145-147.

Murphy, J. and J.P. Riley. 1962. A modified single solution method for the determination of phosphate in natural waters. Analytica chimica acta 27: 31-36.

Nelson, D.W. and L.E. Sommers. 1973. Determination of total nitrogen in plant material 1. Agronomy Journal 65 (1): 109-112.

Nwakaudu, M., F. Kamen, G. Afube, A. Nwakaudu and I. Ike. 2012. Impact of cassava processing effluent on agricultural soil: A case study of maize growth. Journal of Emerging Trends in Engineering and Applied Sciences 3 (5): 881-885.

Orhue, E., E. Imasuen and D. Okunima. 2014. Effect of cassava mill effluent on some soil chemical properties and the growth of fluted pumpkin (Telfairia occidentalis Hook F.). Journal of Applied and Natural Science 6 (2): 320-325.

Osakwe, S. and V. Akpoveta. 2012. Effect of cassava processing mill effluent on physical and chemical properties of soils in Abraka and environs, Delta State, Nigeria. The Pacific Journal of Science and Technology 13 (2): 544- 554.

Ravikumar, P. and R.K. Somashekar. 2013. Evaluation of nutrient index using organic carbon, available $\mathrm{P}$ and available $\mathrm{K}$ concentrations as a measure of soil fertility in Varahi River basin, India. Proceedings of the International Academy of Ecology and Environmental Sciences 3 (4): 330-343.

Romano-Armada N., M.J. Amoroso and V.B. Rajal. 2017. Effect of glyphosate application on soil quality and 
health under natural and zero tillage field conditions. Soil and Environment 36 (2): 141-154

Saha, M., B.R. Maurya, I. Bahadur, A. Kumar, and V.S. Meena. 2016. Can potassium-solubilising bacteria mitigate the potassium problems in India?. p 127-136. In : Potassium Solubilizing Microorganisms for Sustainable Agriculture. V. Meena, B. Maurya, J. Verma and R. Meena (eds.). Springer, New Delhi.

Sharma, S.B., R.Z. Sayyed, M.H. Trivedi and T.A. Gobi. 2013. Phosphate solubilizing microbes: sustainable approach for managing phosphorus deficiency in agricultural soils. Springer Plus 2 (1): 587.

Sieverding, E. and R. Howeler. 1985. Influence of species of VA mycorrhizal fungi on cassava yield response to phosphorus fertilization . Plant and Soil 88(2): 213221.

Soylak, M., A.U. Karatepe, L. Elçi and M. Doğan. 2003. Column preconcentration/separation and atomic absorption spectrometric determinations of some heavy metals in table salt samples using amberlite XAD-1180. Turkish Journal of Chemistry 27 (2): 235-242.
Stewart, J. and H. Tiessen. 1987. Dynamics of soil organic phosphorus. Biogeochemistry 4 (1): 41-60.

Surleva, A., M. Zaharia, L. Ion, R.V. Gradinaru, G., Drochioiu and I. Mangalagiu. 2013. Ninhydrin-based spectrophotometric assays of trace cyanide. Acta Chemica Iasi 21: 57-70.

Walkley, A. and I.A. Black. 1934. An examination of the Degtjareff method for determining soil organic matter, and a proposed modification of the chromic acid titration method. Soil Science 37 (1): 29-38.

Xu, Y., B. Seshadri, B. Sarkar, H. Wang, C. Rumpel, D. Sparks, M. Farrell, T. Hall, X. Yang and N. Bolan. 2018. Biochar modulates heavy metal toxicity and improves microbial carbon use efficiency in soil. Science of the Total Environment 621: 148-159. 